\title{
Methods of resource room management for teachers of learning disabilities in English language in light of some variables
}

\author{
Mohamad Ahmad Saleem Khasawneh* \\ Special Education Department, King Khalid University, Saudi Arabia \\ *Correspondence \\ Email: mkhasawneh@kku.edu.sa
}

$\begin{array}{cccc}\text { Received: } & \text { Revised: } & \text { Accepted: } & \text { Published: } \\ \text { 13 April 2021 } & \text { 10 August 2021 } & \text { 23 August 2021 } & \text { 31 August 2021 }\end{array}$

\begin{abstract}
This study aimed at identifying the methods of managing the resource room for teachers of English language learning disabilities in the light of some variables. The study population consisted of all (60) teachers of English language learning disabilities in the upper basic stage in Irbid Governorate. The sample of the study consisted of (30) female and male teachers. The study used the descriptive methodology, for which a questionnaire was developed to collect and test data. The results of the study showed that the democratic method ranked first with a mean score of (4.13) and a standard deviation of (0.59), and the autocratic method came in the second rank with a mean score of (2.30) and a standard deviation of (0.57). The laissez-faire method came in the last rank with a mean score of (1.96), and a standard deviation of (1.96).
\end{abstract}

Keywords: autocratic method; laissez-faire method; democratic method; learning disabilities; English language

\section{INTRODUCTION}

The school administration is based on achieving the school's mission through its direct relationship with the students, as it enjoys greater freedom to act and perform the roles entrusted to it, making it the most important administrative unit in the educational administration cycle. Therefore, the school administration is a living entity, consisting of a human group that includes students, the teacher, and those in charge of the administration. The success of the relations between these parties depends on the awareness of each of them of his role, and this effectively affects the success of the educational process, and the extent of its achievement, and thus the message of education can be achieved through classroom management.

The teacher of LDs in English language is the pillar of the educational process, because he is the leader in his class, motivating students, leading them, and pushing them to achieve social, behavioral, and academic goals. Therefore, the teacher should be aware of his appropriate administrative 
Khasawneh, M. A. S. (2021). Methods of resource room management for teachers of learning disabilities in English language in light of some variables. EduLite: Journal of English Education, Literature, and Culture, 6 (2), 213-221. http://dx.doi.org/10.30659/e.6.2.213-221

behavior, and be aware of the environmental and social conditions, in which he works. English language teachers need to work as the main element in organizing classroom management and creating the appropriate atmosphere to carry it out efficiently and effectively. They have to get acquainted well with the characteristics of the students, and the developmental stages to which they belong. Therefore, the methods used by the teacher of LDs in English language in classroom management have the greatest impact on building the student's personality (Al-Sharqawi, 2016).

The management methods used by the teacher of LDs in English in classroom management are also determined by the nature of the age stage of his students. Therefore, the administration of the Ministry of Education in Jordan saw the development of the structure of education by dividing primary education into four educational stages. Among these stages, the upper stage, which aims to develop the abilities and readiness of students, satisfy their tendencies and provide them with the necessary number of values, knowledge, and attitudes. In this stage, students are exposed to physical and psychological changes, making them different from other age groups. This stage seeks to provide and create all the psychological, social, and educational requirements and conditions necessary to achieve the objectives of the educational process (Abboud, 2017). Classroom management means everything that a teacher of English language difficulties does in the classroom, whether direct or indirect, verbal or practical, to achieve the educational and pedagogical goals to meet the desirable change in students' behavior. This occurs by providing them with knowledge and skills, works to help them in practical life, and refines their personalities and talents. Thus, the concept of classroom management can be defined as a process that aims to provide an effective organization through specific conditions necessary for students' learning to occur.

Classroom management methods vary according to the practice. There are multiple classifications of administrative behavior, and the common classification for administrative behavior methods is based on the method of using the authority granted to the English language teacher. The teacher of English language may be autocratic, or democratic, and he may be neither one nor the other, which is called the laissez-faire method (Al-Gufut, 2010).

The teacher of LDs in English language is considered a role model for his students, and the method he practices with his students in the classroom is of great importance to determine the impact he leaves on the students' educational and future lives. The methods used by the LDs in English language teachers in classroom management focus on their personality, academic level, and experiences. All of this determines the management style used by the teacher. Therefore, it is noted that the English language teachers differ among themselves, and this difference generates different methods of classroom management. These methods are represented by the autocratic method, the democratic method, and the laissez-faire method. These methods are connected and similar because it is not easy to classify teachers in specific administrative methods. These types may overlap and the teacher may combine more than one method, but with one specific method that dominates the others. The teacher's use of the laissez-faire method affects students negatively, as it leads to a lack of interest in the system and high achievement by students. The democratic 
method has a very important positive impact on students in developing their personalities and meeting their needs. Therefore, this study attempted to identify the classroom management methods of teachers of LDs in English language in light of some variables in Irbid Governorate from the point of view of teachers themselves. This study attempted to answer the following question: What are the classroom management methods used by teachers of LDs in English language in Irbid Governorate from their point of view?

The significance of this study stems from the fact that it targets an important group in society, which is the category of teachers of LDs in English language. These teachers have a great role in enlightening the minds of successive generations, refining their morals, and have an impact on the formation of the student's personality. The results of this study will be useful for school principals and educational supervisors regarding the best classroom management method. This study also enriches educational research with new studies in classroom management. The study develops future visions for classroom management methods based on the results of this study.

This study was limited to teachers of LDs in English language in the upper basic stage in Irbid Governorate for the academic year (2019-2020). Thus, the results are limited to time and spatial limitations. The results of this study are determined by the response of the study sample to the questionnaire items that were prepared for this study and according to which information was collected.

Classroom management constitutes an important element of the modern educational system because it affects all the elements of this system from inputs, operations, outputs, and feedback. It is an important activity under which many educational concepts, such as planning, implementation, evaluation, and methods of dealing with students are included. It stimulates students' motivation and helps them to comprehensive growth in all aspects of their mental and social personality. Perhaps the teacher of LDs in English language is one of the most important elements that can contribute to achieving this growth and development. For this reason, educators were interested in methods and patterns of dealing with students (Zabel \& Zabel, 2011).

Al-Khataiba, Al-Tweissi, and Al-Sultani (2002) indicated that classroom management refers to all the procedures followed by the teacher of learning disabilities in English to maintain order to ensure the calmness of the students in the classroom. This concept is derived from traditional education that looks at education, as a process of transferring information from books to the minds of students, and the teacher is the transmitter of this information. There is no doubt that this concept is based on authoritarian management.

Classroom management means the processes of direction, leadership, and efforts made by the parties to the educational process in the classroom. This interaction results in the emergence of behavioral patterns, and these efforts must focus on providing the climate to reach the desired goals by defining the roles of the teacher and the student. The classroom environment should be organized in a manner that achieves meaningful learning. Therefore, the methods and styles of management used by the teacher of LDs in English language are the most influential in the students' hearts, because the teacher is the role model for students (Collin, 2010). 
Khasawneh, M. A. S. (2021). Methods of resource room management for teachers of learning disabilities in English language in light of some variables. EduLite: Journal of English Education, Literature, and Culture, 6 (2), 213-221. http://dx.doi.org/10.30659/e.6.2.213-221

Classroom management is an organized process that aims to bring about specific changes in students' behavior and create appropriate conditions that allow them to grow, develop and adapt. Classroom management is one of the important axes that make the teacher of LDs in English language an effective mediator in raising students' learning adequacy and creating educational environments in which students use their maximum potential for learning, growth, and development (Abu Namira, 2001).

This process includes a precise definition of the role of the English language teacher and the student, and what the English language teacher does in organizing educational experiences, materials, and tools that contribute to the conduct of the learning process to the maximum potential of the learner. The process also requires providing the student the opportunity to achieve himself and integrate into the situation to develop an interactive personality (Casey \& Tucker, 1994). Classroom management is the process that allows students complete freedom of movement and provides them with opportunities to choose the activities they want to do (Khalil, 2014).

Al-Badri (2005) pointed out that classroom management is leadership and guiding effort made primarily by the teacher. The students help by accepting this direction in terms of communication, coordination, implementation of proposals, adherence to classroom controls, and proper behavior in the classroom. As a result of these vital practices in the classroom, such as organizing, coordinating, planning, and following up, classroom management appears as a comprehensive, organized process in which inputs are diversified and its tributaries increase, to reach the required educational goal. Therefore, the teacher of LDs in English language should use appropriate methods in proportion to the age stage.

Al-Abdullah and Radwan (2020) investigated the effectiveness of classroom management level among basic stage teachers in Irbid governorate schools from the principals' point of view. The study explored the impact of the variables of gender, qualification, and years of experience on the principals' responses. The study was applied to a sample of (243) principals. The study used the descriptive analytical methodology by developing a questionnaire of (32) items. The results revealed that the great impact of classroom management level among teachers. The findings also showed that there was no effect for all variables in principals' responses to the questionnaire.

Rawadiyah (2020) explored the extent to which the teachers of the basic stage in the southern Badia schools have classroom management skills. The study used the descriptive-analytical approach and developed the study instruments, which was applied to a sample of (130) teachers. The results of the study showed that teachers possessed high classroom management skills. The classroom environment field ranked first, followed by administrative skills, classroom problem solving, technical skills, and knowledge structure. There was no impact of gender or experience on possessing the skills of classroom management among teachers.

Aba Oud (2020) investigated the level of teachers' efficiency in their classroom management with students with emotional/behavioral disorders. The study included (437) elementary school teachers in Riyadh. The study used the 
descriptive approach. The results revealed that the levels of teachers' efficiency in classroom management were average. There was a positive relationship between the efficiency of classroom management and the demographic characteristics of teachers.

Al-Mutairi (2019) explored the extent of efficiencies achieved in successful classroom management-related skills among Islamic education teachers in primary school. The study used the descriptive-analytical approach and was applied to (25) teachers. The study used a notecard covering personal and cognitive skills. The results revealed a high level of efficiency among the sample of the study.

Ali and Al-Bashatowa (2019) explored the problems of classroom management facing the teachers of students with special needs in Najran. The sample of the study included (30) specialized teachers. The study used a questionnaire to collect data. The findings showed that BA holders had fewer problems than other teachers. The results also showed that teachers with experience of more than 6 years and who attended more training courses had fewer problems than other teachers.

Al-Anazi and Al-Shanba (2018) identified the role of the supervisory department in activating the alternative Evaluation in the programs of the Ministry of Education in secondary school in the governmental schools in Saudi Arabia. The study also developed a program to enhance students by using classroom and non-classroom activities. The study mentioned several methods, including self-assessment and peer evaluation, the assessment based on the achievement file, and other methods. The study found several restrictions to the alternative assessment process. For example, students feel uncomfortable introducing a new kind of evaluation and teachers hate to change from the traditional evaluation to the new methods. The study suggested preparing a guide for the teacher towards the use of methods of alternative assessment methods.

Platt (1979) conducted a study aimed at identifying the methods used in the classroom with students in primary schools in the state of California. The study sample consisted of (120) primary school teachers in California. The study found that traditional authoritarian methods to dealing with students in the classroom are less effective. The democratic methods in dealing with students in the classroom are more effective, and the laissez-faire methods are weaker in classroom management.

\section{METHODS}

Population and Sample

The study population consisted of all female and male (60) teachers of learning disabilities in English language difficulties in the upper basic stage in Irbid governorate. The study sample consisted of (30) male and female teachers.

\section{Research Instrument}

The study developed a questionnaire as an instrument of the study to identify the classroom management methods of teachers of LDs in English language in 
Khasawneh, M. A. S. (2021). Methods of resource room management for teachers of learning disabilities in English language in light of some variables. EduLite: Journal of English Education, Literature, and Culture, 6 (2), 213-221. http://dx.doi.org/10.30659/e.6.2.213-221

the upper basic stage in Irbid Governorate. The previous studies and literature related to the subject of the study were reviewed to develop the instrument.

The questionnaire was presented to (12) judges from faculty members with experience in special education to ensure the clarity and integrity of the wording of the paragraphs. They were asked to provide their opinions to ensure the validity of the statements to measure what they were designed to measure. Based on the judges' opinions, modifications were made to the questionnaire. The judges' approval of the content of each statement of the instrument was considered $(80 \%)$ or more indicative of the validity of the statement.

After confirming the validity of the study instrument, its reliability was confirmed using the test-re-test method, by applying it to a sample from outside the study sample. The reliability was also ensured by extracting the Pearson correlation coefficient between the responses of the sample members in the first test and the second test. The statistical analysis showed that the stability of the instrument on the Pearson correlation coefficient on average was (0.89) for the instrument as a whole, which is an acceptable percentage to conduct the study.

\section{RESULTS AND DISCUSSION}

Results of the question of the study

What are the classroom management methods used by teachers of LDs in English language in Irbid Governorate from their point of view? To answer this question, the mean scores and standard deviations were extracted for the questionnaire and responses of the study sample, as presented in the following table.

Table 1. Mean scores, standard deviations, and ranks of the classroom management methods arranged in descending order according to the mean score

\begin{tabular}{cccc}
\hline $\begin{array}{c}\text { Management } \\
\text { method }\end{array}$ & Mean score & $\begin{array}{c}\text { Standard } \\
\text { deviation }\end{array}$ & Rank \\
\hline Democratic & 1 & 0.59 & 4.13 \\
\hline Autocratic & 2 & 0.57 & 2.30 \\
\hline Laissez-faire & 3 & 0.71 & 1,96 \\
\hline
\end{tabular}

It is clear from Table 1 that the democratic method ranked first with a mean score of (4.13) and a standard deviation of (0.59). The autocratic method came in the second rank with a mean score of (2.30) and a standard deviation of (0.57). However, in the last rank came the laissez-faire method with a mean score of (1.96) and with a standard deviation of (1.96).

The classroom is dominated by several management options and alternatives of knowledge, activities, materials, and tools, which are harmonious and attainable. The activity of the learner increases and he exercises the role of organizer and preparer of activities. The students participate in classroom management. Using the democratic management style as one of the most important leadership styles in class management is very productive and 
important. This method is represented in treating the treatment of teachers of LDs in English to the students as friends, taking into account the students' desires as a basic criterion when choosing or developing his activity, and taking into account objectivity in dealing with students' problems. This method focuses on their humanity and responding to their individual needs, equanimity, and poise in the face of difficulties, tolerance, humility, and openness to captivity during their dealings and actions.

\section{CONCLUSION}

This study attempted to identify the classroom management methods of teachers of LDs in English language in light of some variables in Irbid Governorate from the point of view of teachers themselves. The results of this study found that the democratic management style was dominant among the different management styles. The result of this study was in agreement with previous studies (Smith, 2000; Muller, 2005), whose results indicated that the use of tolerant democratic behavior by teachers of LDs in English language during teaching develops creativity and independence among students, classroom management. On the other hand, the authoritarian style is the weakest of the classroom management methods, which agrees with previous studies (Al-Shami, 2012; Al-Qarni, 2000). These studies indicated that the most common style or method among teachers is the democratic, tolerant style of classroom management.

In light of the findings of the study, the researcher presents a set of recommendations related to these results, as follows: First, the Ministry of Education should hold training courses and educational meetings to introduce the new English language difficulties teacher to classroom management methods. Second, the researcher recommends conducting studies of classroom management methods in other educational stages.

\section{ACKNOWLEDGMENTS}

The authors extend their appreciation to the Deanship of Scientific Research at King Khalid University for funding this work through Big Research Groups under grant number (RGP.2 / 103/42).

\section{REFERENCES}

Aba Oud, A. A. (2020). Efficiency of classroom management with students with emotional behavioral disorders and its relationship to the demographic characteristics of their teachers. Journal of the College of Education in Psychological Sciences: Ain Shams University - College of Education, 44(4), 303328. http://search.mandumah.com/Record/1117545

Abboud, A. (2017). Primary school administration. 7th ed. Dar Al-Nahda Publishing.

Abu Namira, M. K. (2001). Classroom Management and Organization. 1st Edition. Dar Jaffa for Publishing and Distribution. 
Khasawneh, M. A. S. (2021). Methods of resource room management for teachers of learning disabilities in English language in light of some variables. EduLite: Journal of English Education, Literature, and Culture, 6 (2), 213-221. http://dx.doi.org/10.30659/e.6.2.213-221

Al-Abdullah, R. Y., \& Radwan, A. M. (2020). The effectiveness of classroom management level among basic stage teachers in Irbid Governorate Schools as perceived by their principals. Journal of the Islamic University of Educational and Psychological Studies: The Islamic University of Gaza - Scientific Research and Graduate Studies Affairs, 28(3), 589-606. http:// search.mandumah.com/Record/1089221

Al-Anazi, A. A., \& Al-Shanba, H. A. (2018). The role of supervisory administration in activating alternative evaluation in vocational rehabilitation programs. The Arab Journal of Educational and Human Sciences Studies and Research, 13, 1-33. http://search.mandumah.com/Record/971267

Al-Badri, T. (2005). Classroom education management. 1st ed. Dar Al Thaqafa for Publishing.

Al-Gufut, W. (2010). Classroom Management. Teacher's Message Journal, 4, issue 1 and 2. pp (8-14).

Al-Khataiba, M., Al-Tweissi, A., \& Al-Sultani, A. (2002). Classroom interaction. Ed 1. Dar Yazid for publishing.

Al-Mutairi, M. H. (2019). Successful classroom management efficiencies attained in elementary teacher in the State of Kuwait. Journal of the Faculty of Education: Kafrelsheikh University - Faculty of Education, 19(4), 579-608. http://search.mandumah.com/Record/1041087

Al-Qarni, A. S. (2000). The relationship between the leadership styles used by secondary school principals in Riyadh and the two styles of work and the interaction of the English language difficulties teacher with students in the classroom. Unpublished master's thesis, University of Jordan, Amman, Jordan.

Al-Shami, K. (2012). Classroom management methods practiced by primary school teachers in Karbala Governorate. Unpublished master's thesis, University of Baghdad.

Al-Sharqawi, M. (2016). Distinguished classroom administration. Dar Al-Nahda Publishing.

Ali, H. I. M., \& Al-Bashatowa, R. H. A. (2019). The problems of classroom management facing the teachers of students with special needs in the comprehensive rehabilitation center in Najran. Journal of Educational and Psychological Sciences: The National Research Center Gaza, 3(26), 56-73. http://search.mandumah.com/Record/1037451

Casey, M. B., \& Tucker, E. C. (1994). Problem-centered classrooms. Phi Delta Kappan, 76(2), 139-143.

Collin, J. (2010). Smith and Robert Laslett: Effective Classroom Management a Teacher's Guide, Second Edition. Routledge.

Khalil, M. A. (2014). Classroom Management, ed 9. Al-Quds Open University Publications.

Muller, W, (2005). The need for teacher training and a training model to promote democratic teaching behavior.

Platt, A. R. (1979). Efficacy of class meetings in elementary schools. Unpublished Master's thesis. California State University, Sacramento.

Rawadiyah, K. H. (2020). The extent to which teachers of the basic stage in Southern Badia Education Schools possess classroom management skills and their relationship to learning outcomes and social relationships between students. 
EduLite Journal of English Education, Literature, and Culture

Vol. 6, No. 2, August 2021, pp. 213-221

E-ISSN: 2528-4479, P-ISSN: 2477-5304

http://jurnal.unissula.ac.id/index.php/edulite DOI: http://dx.doi.org/10.30659/e.6.2.213-221

Journal of Educational and Psychological Sciences: The National Research Center Gaza, 4(7), 38-62. http://search.mandumah.com/Record/1046530

Smith, D. (2000). Classroom management and consolation: Implications for School Psychology. Psychology Schools, 18(4),575-481.

Zabel, R, \& Zabel, M. (2011). Classroom Management in Context, Orchestrating Positive Learning Environments. Boston Houghton Mifflin Company. U.S.A.

Conflict of Interest Statement: The authors declare that the research was conducted in the absence of any commercial or financial relationships that could be construed as a potential conflict of interest.

Copyright (C) 2021 Khasawneh. This is an open-access article distributed under the terms of the Creative Commons Attribution License (CC BY). The use, distribution or reproduction in other forums is permitted, provided the original author(s) and the copyright owner(s) are credited and that the original publication in this journal is cited, in accordance with accepted academic practice. No use, distribution or reproduction is permitted which does not comply with these terms. 